\title{
Determinant Factors of Hypertension in pre-geriatric group (18-35 years old) in Surabaya
}

\author{
Minarni Wartiningsih ${ }^{1}$, Stefanus Supriyanto ${ }^{2}$, Hanna Tabita Hasiana Silitonga ${ }^{3}$, I \\ Made Irham Muhammad ${ }^{4}$, Glory Taby Palloan ${ }^{4}$, Muhammad Faza Budargo $^{4}$ \\ ${ }^{1}$ Doctoral of Faculty of Public Health, Universitas Airlangga, 60115 Surabaya, Indonesia \\ ${ }^{2}$ Lecturer of Faculty of Public Health, Universitas Airlangga, 60115 Surabaya, Indonesia \\ ${ }^{3}$ Lecturer of Medical School of Universitas Ciputra ,CitraLand CBD Boulevard Surabaya 60219, \\ Indonesia \\ ${ }^{4}$ Student of Medical School Universitas Ciputra, CitraLand CBD Boulevard Surabaya 60219, Indonesia \\ Email: minarni.wartiningsih@ciputra.ac.id
}

\begin{abstract}
Background: Hypertension data based on age groups in Surabaya showed an increase in hypertension trends in the young age group. It is known that hypertension risk factors are gender, behavior or lifestyle, age, sex, race/ethnicity, genetics, effective stress management, and obesity. Of all these risk factors, behavioral factors or specifically referred to as lifestyle are closely related to hypertension morbidity in the aged 18-35 years. Objective: The aims of this study is to determine the determinants that most influence the incidence of hypertension in order to reduce the prevalence of hypertension at 18-35 years old in the western and eastern parts of the city of Surabaya. Method: This studi employed cross-sectional observational analysis using Chi Square and logistic regression. Sample of this studi were 404 respondents taken by Cluster Random Sampling, with inclusion criteria as follows: 18-35 years old, currently not in hypertension medication, never having a stroke and suffering from a heart condition. The respondent's blood pressure check is carried out before and after completing the questionnaire. Results: The results of research shows unfavorable behavior towards healthy lifestyle, smoking behavior, exercise, fast food consumption, stress, and sleep time have significant results on the incidence of hypertension. Of all factors, smoking behavior was the highest $(p=0,000 ; O R$ 14,366). Conclusion: To prevent an increase in the prevalence of hypertension in 18-35 years, it is necessary to implement regulation of non-smoking area.
\end{abstract}

Keywords: hypertension, smoking behavior, fast food consumption behavior, lifestyle, stress behavior, sleeping behavior

\section{INTRODUCTION}

Hypertension is one of global mortality risk factors. In 2015, hypertension prevalence in people aged 18 years or more was $20 \%$ in females and 24\% in males (World Health Organizati, 2017). Hypertension has contributed in a risk increase of cardiovascular diseases as well as stroke, disability, and early mortality (World Health Organization, 2013). In certain age groups, the risk of cardiovascular diseases has doubled for every increase of blood pressure as much as $20 / 10 \mathrm{mmHg}$ started from $115 / 75$ $\mathrm{mmHg}$ (World Health Organization, 2017). Hypertension prevalence is commonly found in low income and middle income countries in people with low body immune system. Other factors causing high prevalence of hypertension in both low income and middle income countries are weak health system, undetected/undiagnosed hypertension patients, and lack of proper management/intervention for the patients. In 2008, it was obtained that hypertension prevalence in low income countries was higher (40\%) compared to the one in high income countries (35\%) (World Health Organization, 2013).

In Indonesia, hypertension has become the third cause of mortality, just after stroke and tuberculosis which was $6.7 \%$ in all age groups (Kementerian Kesehatan, 2010). Based on Riskesdas 
(Basic Health Research) Indonesia in 2013, hypertension prevalence has decreased from $31.7 \% \quad(2007)$ to $25.8 \% \quad(2013)$. However, only $9.5 \%$ was diagnosed out of $25.8 \%$ of hypertension patients. This means that the scope of medical personnel was only reaching $36.8 \%$. Most of hypertension cases in public have not been diagnosed (63.2\%) (Badan Penelitian dan Pengembangan Kesehatan, 2013). In 2017, based on research result of Sirkesnas (National Health Indicator Survey), the government's target to reduce hypertension prevalence was $23.4 \%$. Despite the target, the data have shown that hypertension prevalence above 18 years old have only reached $32.4 \%$. From the $32.4 \%$ of hypertension patients, the ones diagnosed by medical personnel were only $12.9 \%$. Hence, most of hypertension cases $(60.2 \%)$ in public have not been diagnosed (Badan Penelitian dan Pengembangan Kesehatan, 2016).

In Indonesia, East Java has more hypertension prevalence exceeding the national's prevalence which is $26.2 \%$. In 2013, according to Riskesdas data, Surabaya experienced a decrease of hypertension prevalence from 26.4\% (2007) to 22\% (2013). However, of $22 \%$ hypertension patients, only $14.4 \%$ were diagnosed. This indicates that the scope of medical personnel was only $65 \%$. Therefore, there are $35 \%$ of undiagnosed patients (Balitbangkes Kemenkes RI, 2013). Besides, data of PTM (non communicable Diseases) of Health Office of Surabaya in 2017 have indicated that hypertension ranked first among non communicable diseases reaching 101,635 cases. Hypertension case trend in Surabaya during 2014-2017 was dominated by geriatrics group. Besides, hypertension case in pre-geriatrics group $(<45$ years old) has also been increasing. This needs further follow-up medical efforts aiming to reduce the number of hypertension patients in the age group in order to prevent its complication during geriatrics. One of efforts that can be done is my controlling the hypertension risk factors. Hypertension risk factors such as gender, behavior or lifestyle, age, sex, race/ethnicity, genetics, effective stress management, and obesity (Sani et al., 2010; Abed and Abu-Haddaf, 2013; WHO, 2019). Based on the data and exposition of the problems, this research was conducted aiming to analyze behavior/lifestyle of 18-35 years in Surabaya who are prone to hypertension occurrence.

\section{METHODS}

This research is an analytical observational study with cross sectional research design. The population of the study was people aged between 18-35 years old residing in West Surabaya and East Surabaya. States selection for this study based on data from Health Office of Surabaya City, which states that highest prevalence of hypertension in primary health care in East Surabaya and West Surabaya. The samples of the study were 404 respondents. The research sampling technique was cluster random sampling. Sampling by selecting 10 sub-districts in West and East Surabaya randomly. Then, each sub-district was taken 4 random villages and each village sample consist of 10-11 sample. The dependent variable of the research is blood pressure, while the independent variables are lifestyles including healthy consumption behavior, exercise behavior, smoking behavior, alcohol consumption behavior, stress behavior, sleeping behavior, and fast food consumption behavior. The data are obtained through self-administered questionnaire filling for approximately 1530 minutes by each respondent. The data analysis was first done using crosstab to observe relationship between both dependent and independent variables, and next by using logistic regression to see the relationship power.

\section{RESULT AND DISCUSSION}

There are two types of hypertension risk factors, include modified risk factors and risk factors that cannot be modified. Risk factors that cannot be modified are demographics factors, while risk factors that can be modified are lifestyle.

\section{Demographics Factors}

Based on research results, the majority of respondents are female as many as 279 respondents $(69.1 \%)$ and men as many as 125 respondents (30.9\%). The majority of ethnic groups are Javanese as many as 242 respondents (59.9\%), Chinese 
74 respondents $(18.3 \%)$ and others 88 respondents $(21.8 \%)$.

Table 1. Frequency Distribution of Demographics Factors

\begin{tabular}{|c|c|c|}
\hline $\begin{array}{l}\text { Respondent's } \\
\text { Characteristic }\end{array}$ & Frequency & percentage \\
\hline \multicolumn{3}{|l|}{ Sex } \\
\hline Female & 279 & $69.1 \%$ \\
\hline Male & 125 & $30.9 \%$ \\
\hline \multicolumn{3}{|l|}{ Race/Ethnicity } \\
\hline Javanese & 242 & $59.9 \%$ \\
\hline Chinese & 74 & $18.3 \%$ \\
\hline Others & 88 & $21.8 \%$ \\
\hline \multicolumn{3}{|l|}{ Employment } \\
\hline College Students & 207 & $51.2 \%$ \\
\hline Employee & 197 & $48.8 \%$ \\
\hline \multicolumn{3}{|l|}{ Hypertension } \\
\hline Yes & 47 & $11.6 \%$ \\
\hline No & 357 & $88.4 \%$ \\
\hline \multicolumn{3}{|c|}{ Body Mass Index (BMI) } \\
\hline Under & 38 & $9.4 \%$ \\
\hline Normal & 245 & $60.6 \%$ \\
\hline Over & 86 & $21.3 \%$ \\
\hline Obese & 35 & $8.7 \%$ \\
\hline \multicolumn{3}{|l|}{ Family History } \\
\hline Yes & 138 & $34.2 \%$ \\
\hline No & 266 & $65.8 \%$ \\
\hline Total & 404 & $100.0 \%$ \\
\hline
\end{tabular}

Most of respondent's is a college student as many as 207 respondents (51.2\%). The characteristics of body mass index (BMI) shows that the majority of respondents have a normal BMI as many as 245 respondents (60.6\%). Most respondents are known to have no family history of hypertension, totaling 266 respondents (65.8\%).

Based on Table 2 it can be seen that there are more non-smoker respondents (89.9\%) compared to the smoker respondents with average number of 3-5 cigarette sticks on daily basis. Most of the respondenst $(83.9 \%)$ also did not consume alcohol. Most respondents as many as 214 respondents do exercising (53\%) with average duration of $>30$ minutes. Average number of respondents as many as 211 respondents had healthy consumption behavior (52.2\%) and 320 respondents do not consume fast food (79.2\%). Next, as many as 212 respondents (52.5\%) suffer from stress due to several reasons, including financial problem, homework, and job. In terms of sleeping behavior, most respondents as many as 254 respondents state that they have proper time to sleep which is $>6$ hours $(62.9 \%)$.

\section{Smoking Behavior}

Table 3 indicates that there is a relationship between smoking behavior and hypertension prevalence with a significance level of $0.000 \quad(<0.05)$. As many as 321 (94.7\%) non-smoker respondents don't have hypertension. Respondents who smoke and spend 3-5 cigarettes a day has a reason to relieve stress or just make him calm down.

Table 2. Frequency Distribution of Lifestyle of 18-35 Years in Surabaya

\begin{tabular}{|c|c|c|c|}
\hline Factor & Category & Frequency & Percentage \\
\hline \multirow{2}{*}{ Smoking Behavior } & Yes & 65 & $16.1 \%$ \\
\hline & No & 339 & $83.9 \%$ \\
\hline \multirow{2}{*}{ Alcohol Consumption Behavior } & Yes & 65 & $16.1 \%$ \\
\hline & No & 339 & $83.9 \%$ \\
\hline \multirow{2}{*}{ Exercise Behavior } & Yes & 214 & $53.0 \%$ \\
\hline & No & 190 & $47.0 \%$ \\
\hline \multirow{2}{*}{ Healthy Food Behavior } & Yes & 211 & $52.2 \%$ \\
\hline & No & 193 & $47.8 \%$ \\
\hline \multirow{2}{*}{ Fast Food Consumption Behavior } & Yes & 84 & $20.8 \%$ \\
\hline & No & 320 & $79.2 \%$ \\
\hline \multirow{2}{*}{ Stress Behavior } & Yes & 212 & $52.5 \%$ \\
\hline & No & 192 & $47.5 \%$ \\
\hline \multirow{2}{*}{ Sleeping Behavior } & $<6$ hours & 150 & $37.1 \%$ \\
\hline & $>6$ hours & 254 & $62.9 \%$ \\
\hline Total & & 404 & $100 \%$ \\
\hline
\end{tabular}


In cardiovascular diseases, smoking can cause temporary increase of blood pressure as well as trigger damaged the endothelium (the lining of the blood vessels, increases fatty deposits in the arteries, increases clotting, raises lowdensity lipoprotein cholesterol, reduces high-density lipoprotein and promotes coronary artery spasm. Nicotine ones of component of cigarettes that causes addiction, accelerates heart rate and increases blood pressure (World Health Federation, 2017). Passive smokers exposed to smoke are very likely of having a risk of suffering from cardiovascular diseases and hypertension (Centers for Disease Control and Prevention, 2019). Cigarettes cause vasoconstriction of peripheral arteries and blood vessels in kidneys so can increases blood pressure. Smoking cigarettes every day increases systolic pressure of $10-25 \mathrm{mmHg}$ and increases heart rate 5-20 times per minute. Other studies shown there are differences of $2 \mathrm{mmHg}$ systolic blood pressure against groups of smokers and nonsmokers measured at age over 16 years grouped according to age intervals every 4 years (Primatesta et al., 2001). A research by Yulia has also stated that there is a relationship between smoking and hypertension prevalence $(p=0,000)$ (Yulia, 2015). There is a relationship between smoking habit and hypertension prevalence with $p$-value of 0.000 (Spearman correlation test) (Memah, Kandou and Nelwan, 2019).

Table 3. Relationship between Hypertension Prevalence and Lifestyle of 18-35 years in Surabaya

\begin{tabular}{|c|c|c|c|c|c|c|c|c|}
\hline \multirow{3}{*}{ Lifesty } & & \multicolumn{4}{|c|}{ Hypertension } & \multirow{2}{*}{\multicolumn{2}{|c|}{ Total }} & \multirow{3}{*}{ sig. } \\
\hline & & \multicolumn{2}{|c|}{ Yes } & \multicolumn{2}{|c|}{ No } & & & \\
\hline & & $\mathrm{n}$ & $\%$ & $\mathbf{N}$ & $\%$ & $\mathrm{n}$ & $\%$ & \\
\hline \multirow{2}{*}{ Smoking Behavior } & Yes & 29 & 44.6 & 36 & 55.4 & 339 & 100 & \multirow{2}{*}{0.000} \\
\hline & No & 18 & 5.3 & 321 & 94.7 & 65 & 100 & \\
\hline \multirow{2}{*}{$\begin{array}{c}\text { Alcohol } \\
\text { Consumption } \\
\text { Behavior }\end{array}$} & Yes & 7 & 10.8 & 58 & 89.2 & 339 & 100 & \multirow{2}{*}{0.979} \\
\hline & No & 40 & 11.8 & 299 & 88.2 & 65 & 100 & \\
\hline \multirow{2}{*}{ Exercise Behavior } & Yes & 20 & 9.3 & 194 & 90.7 & 190 & 100 & \multirow{2}{*}{0.172} \\
\hline & No & 27 & 14.2 & 163 & 85.8 & 214 & 100 & \\
\hline \multirow{2}{*}{$\begin{array}{c}\text { Healthy } \\
\text { Consumption } \\
\text { Behavior } \\
\end{array}$} & Yes & 21 & 10.0 & 190 & 90.0 & 193 & 100 & \multirow[b]{2}{*}{0.344} \\
\hline & No & 26 & 13.5 & 167 & 85.8 & 211 & 100 & \\
\hline \multirow{2}{*}{$\begin{array}{c}\text { Fast Food } \\
\text { Consumption } \\
\text { Behavior }\end{array}$} & Yes & 30 & 44.9 & 54 & 55.1 & 320 & 100 & \multirow{2}{*}{0.000} \\
\hline & No & 17 & 1.0 & 303 & 99.0 & 84 & 100 & \\
\hline \multirow{2}{*}{ Stress Behavior } & Yes & 40 & 18.9 & 172 & 81.1 & 192 & 100 & \multirow{2}{*}{0.000} \\
\hline & No & 7 & 3.6 & 185 & 96.4 & 212 & 100 & \\
\hline \multirow{2}{*}{$\begin{array}{l}\text { Sleeping } \\
\text { Behavior }\end{array}$} & Yes & 10 & 24.7 & 244 & 96.1 & 150 & 100 & \multirow{2}{*}{0.000} \\
\hline & No & 37 & 3.9 & 113 & 75.3 & 254 & 100 & \\
\hline \multicolumn{2}{|c|}{ Total } & 357 & 11.6 & 357 & 88.4 & 404 & 11.6 & \\
\hline
\end{tabular}

\section{Alcohol Consumption Behavior}

According Table 3, as many as 299 non-drinker respondents $(88.2 \%)$ do not suffer from hypertension. Alcohol consumption behavior in question was drink alcohol until drunk. The reason of some respondents drink alcohol to having calm effect when they are tired and stressed out from his work. Based on ChiSquare statistical test, it was obtained the $p$-value or significance level of 0.979 which means that there is no relationship between alcohol consumption behavior and hypertension prevalence. The description of frequency/number of alcohol consumption behavior against hypertension in this study is in line with other. The result has indicated that despite there is a relationship between alcohol consumption behavior and hypertension prevalence, non-drinkers indeed experience level-1 hypertension (Grace et al., 2018). Hypertension is a multifactorial disease where alcohol is not 
the main factor causing hypertension occurrence. But, it has been long known that drinking alcohol is related to the risk of hypertension (Pajak et al., 2013; MedlinePlus, 2017). The consumption pattern of binge drinkers is also associated with higher blood pressure levels compared to non consumers (Pajak et al., 2013). These effect on females an male seem to different, being more likely to be raised by alcohol consumption in male drinks (Sesso et al., 2008; Wakabayashi, 2008). Continued alcohol consumption across several days creates a more sustained rise in blood pressure

\section{Exercise Behavior}

Table 3 shows respondents who did exercise behavior did not has hypertension. Exercise behavior means respondents do physical activity such as walking, running, or light exercise about 30 minutes daily basis. Based on ChiSquare statistical test, it was obtained the $p$-value of 0.172 meaning that there is no relationship between exercise behavior and hypertension prevalence. This result is in accordance with a research by Nur which has indicated that there is no significant relationship between exercising and hypertension prevalence $(p=0,211: \quad$ OR= 1,690) (Haryadi, 2016). Based on OR result, it can be declared that good practice of exercising can reduce the hypertension prevalence as many as 1.690 times compared to bad practice of exercising. This implies that exercise is not the main factor causing hypertension prevalence. However, lifestyle is one of important factors of hypertension prevalence experienced by someone, including the one belonging to young adult age group. The increasing hypertension prevalence has been affected by unhealthy lifestyle, namely lack of exercise (Sriani, Fakhriadi and Rosadi, 2016). Another research has indicated that physical activities do not correlate to blood pressure in hypertension patients $(p$ value $=0,50)$ (Lestari, 2017). For someone suffering from hypertension, exercising can help in preventing hypertension resulting in unnecessary medication consumption to reduce blood pressure. Exercises can help improve the efficacy of medicine consumed by hypertension patients. However, exercises cannot be done by someone having diastolic blood pressure more than $170 \mathrm{mmHg}$ or diastolic blood pressure exceeding $110 \mathrm{mmHg}$. Respondents having similar condition should do low impact physical exercises such as jogging since it is easier to do (Sarumaha and Diana, 2018). According to American Heart Association someone having physically inactive lifestyle has a higher risk of suffering from hypertension compared to those who are doing proper amount of physical activities.

\section{Healthy Consumption Behavior}

According Table 3, shows the result of chi-square analysis has indicated there is no significant relationship between healthy consumption behavior and hypertension prevalence $(p=0.344)$. In terms of percentage, respondents with healthy consumption behavior have better chance not suffering from hypertension (90\%) compared to the ones suffering from hypertension (10\%). The current result is in line with a research conducted by Wijaya where the result has shown that there is no relationship between dietary habit with hypertension prevalence $(p$-value $=0.283) \quad($ Wijaya, 2011). The dietary consumption cannot simply ignore consuming healthy food or just routinely consumption without paying attention on nutrient intake or healthy food composition, especially for patients of hypertension. Based on American Heart Association healthy food diet like consuming fruit and vegetable can help reducing blood pressure. Diet is one attempt of nonpharmacological management of hypertension. An attempt to limit salt intake until $<2,400 \mathrm{mg} /$ day can bring positive impacts for someone's health who is having a risk of suffering from hypertension.

\section{Fast Food Consumption Behavior}

Table 3 shows most respondents suffering from hypertension are respondents consuming fast food which is as many as $44.9 \%$. Fast food consumption behavior means respondents eat fast food 3-5 times a week. The result of chi-square analysis has revealed that there is a significant relationship between behavior of consuming fast food and hypertension prevalence with $p=0.000$. This result has been consistent with the study done by Pratiwi and Anita has indicated that there is a significant relationship between consumption behavior of consuming fast 
food and hypertension prevalence with $p$ value $=0.003 \quad(<0.05)$ and $r_{\text {calculated }}$ coefisient with a positive value of 0.451 (Pratiwi and Anita, 2010). This means that the higher the level of fast food consumption behavior, the higher the hypertension prevalence and vice versa.

\section{Stress Behavior}

Table 3 shows most respondents has stress behavior, its means respondents cannot do handle stress well. This study shows relationship between stress behavior and hypertension prevalence with $p$-value $=0.000$. Hypertension prevalence is more often among respondents suffering from stress $(18.9 \%)$ compared to those who are not stressful $(3.6 \%)$. Another study revealing that there is relationship between stress and hypertension prevalence in people aged 35-45 years old $(p$-value $=0.000)$ (Hartati, Kemalahayati and Zulfikar, 2019). Someone under pressure who has difficulty in managing stress has a higher risk suffering from hypertension compared to those who are not stressful. Stress can affect people's behavior related to unhealthy dietary habit, lack of physical activities, excessive alcohol consumption, etc (American Heart Association, 2014).

\section{Sleeping Behavior}

Table 3 shows respondents who has good sleeping behavior do not experience hypertension. Respondents who has bad sleeping behavior has risk of hypertension. There is relationship between sleeping behavior and hypertension prevalence (Suci Khasanah, 2019). When people sleep, the body relaxes, including the cardiovascular system. The body's systems are going to be dominated by the work of parasympathetic nerves in which when it works, the cardiovascular system will be decreasing. When people sleep, the body is dominated by parasympathetic nerves. The effect of the nerves in the cardiovascular system is that by increasing its work. Another in line research, the study has shown that sleeping pattern is the most influential variable to hypertension prevalence compared to other variables such as sex and age. Based on the calculation of Exp (B) or OR value which was 9.022 which means that people having bad sleeping behavior have 9.022 higher risk of suffering from hypertension compared to the ones having good quality of sleep (Martini, Roshifanni and Marzela, 2018).

Table 4. Analysis of Bivariate and Backward multivariate method

\begin{tabular}{|c|c|c|c|}
\hline Independent Variables & $P$ value & Information & \\
\hline \multicolumn{4}{|l|}{ Step 1} \\
\hline Smoking Behavior & 0.000 & $\begin{array}{c}\text { Candidate } \\
\text { Not }\end{array}$ & \\
\hline Alcohol Consumption Behavior & 0.813 & Candidate & \\
\hline Excersise Behavior & 0.130 & $\begin{array}{c}\text { Candidate } \\
\text { Not }\end{array}$ & $P<0.25$ \\
\hline Healthy Consumption behavior & 0.272 & Candidate & \\
\hline Sleeping Behavior & 0.000 & Candidate & \\
\hline Stress Behavior & 0.000 & Candidate & \\
\hline Fast Food Consumption Behavior & 0.000 & Candidate & \\
\hline Step 2 & $P$ Value & OR & $(95 \% \mathrm{Cl})$ \\
\hline Smoking Behavior & 0.000 & 51.510 & $(10.604-250.224)$ \\
\hline Excersise Behavior & 0.260 & 2.177 & $(0.563-8.417)$ \\
\hline Fast Food Consumption Behavior & 0.000 & 12.824 & $(3.288-50.020)$ \\
\hline Stress Behavior & 0.016 & 6.051 & $(1.406-26.038)$ \\
\hline Sleeping Behavior & 0.002 & 11.494 & $(2.535-52.119)$ \\
\hline Step 3 & $\mathrm{P}$ Value & $\mathrm{OR}$ & $(95 \% \mathrm{Cl})$ \\
\hline Smoking Behavior & 0.000 & 40.646 & $(9.427-175.249)$ \\
\hline Fast Food Consumption Behavior & 0.000 & 14.17 & $(3.671-54.694)$ \\
\hline Stress Behavior & 0.020 & 5.521 & $(1.312-23.243)$ \\
\hline Sleeping Behavior & 0.002 & 11.110 & $(2.511-49.165)$ \\
\hline
\end{tabular}


Table 4 shows that among 4 factors influencing hypertension prevalence, the factor having the biggest influence to the smallest one is smoking behavior (OR= 40.646) which means that smokers have 40.646 times biggest risk of suffering from hypertension compared to the nonsmokers. This research in line with other research about risk factors of primary hypertension prevalence among people aged 20-55 years old in the Polyclinic of Internal Medicine of RSUD 45 Kuningan. According to Chi-Square statistical test, it was obtained the value of $p=<0.001(<a$ $=0.005)$. This means that smoking is a risk factor of primary hypertension prevalence as it is proven by POR value of $=14.3755$, hence the risk of suffering from primary hypertension for smoker respondents is 14.375 more than the risk of their nonsmoker counterparts (Rahmayani, 2019).

The next one is fast food consumption behavior $(O R=14.17)$ which means that people consuming fast food have 14.17 times more risk suffering from hypertension compared to the ones who do not consume fast food. Based on analysis, the $O R$ value of sleeping behavior is $(O R=11.110)$ meaning that people sleeping < 6 hours/day have a bigger risk of 11.110 times suffer from hypertension compared to the ones sleeping > 6 hours/day. According to analysis, it is known that the OR value of stress behavior variable is 5.521 which means that the stressful people have a risk of 5.521 times bigger to suffer from hypertension compared to the ones who are not stressful.

\section{CONCLUSION}

Hypertension is affected by several factors. The dominant factors affecting hypertension prevalence are smoking behavior, fast food consumption behavior, sleeping behavior and stress behavior. Of all dominant factors, smoking behavior was the highest affecting hypertension. There should be intervention of smoking behavior to aged 18-35 years to reduce hypertension prevalence. Interventions can be do active smokers can smoke in the smoking area and college students can make various movements in the fight against cigarettes.

\section{REFERENCES}

Abed, Y. and Abu-Haddaf, S. (2013) 'Risk Factors of Hypertension at UNRWA Primary Health Care Centers in Gaza Governorates', ISRN Epidemiology, 2013, pp. 1-9. doi: 10.5402/2013/720760.

American Heart Association (2014) 'Stress and Heart Health', November. Available at: https://www.heart.org/en/health $y$-living/healthy-lifestyle/stressmanagement/stress-and-hearthealth.

Badan Penelitian dan Pengembangan Kesehatan (2013) Riset Kesehatan Dasar 2013. Jakarta: Kementerian Kesehatan RI.

Badan Penelitian dan Pengembangan Kesehatan (2016) Laporan Survei Indikator Kesehatan Nasional ( Sirkesnas ) 2016. Jakarta: Kementerian Kesehatan RI.

Balitbangkes Kemenkes RI (2013) PokokPokok Hasil Riset Kesehatan Dasar (Riskesdas) 2013 Provinsi Jawa Timur. Jakarta: Kementerian Kesehatan RI.

Centers for Disease Control and Prevention (2019) 'Heart Disease Behavior', 12 November. Available at: https://www.cdc.gov/heartdiseas e/behavior.htm.

Grace, T. G. et al. (2018) 'Hubungan Antara Konsumsi Alkohol dengan Kejadian Hipertensi pada Pasien Rawat Jalan di Puskesmas Kolongan Kecamatan Kalawat Kabupaten Minahasa Utara', 7(5).

Hartati, I., Kemalahayati, C. and Zulfikar (2019) 'Hubungan Stres dengan Kejadian Hipertensi pada Usia 3445 Tahun di Wilayah Kerja Puskesmas Sungai Raya', JP2K, 2(2).

Haryadi, N. N. (2016) 'Analisis faktor risiko kejadian hipertensi di wilayah kerja puskesmas donorojo kabupaten pacitan', Naskah Publikasi.

Kementerian Kesehatan (2010) 'HIPERTENSI PENYEBAB KEMATIAN NOMOR TIGA'. Pusat Komunikasi Publik, Sekretariat Jenderal Kementerian Kesehatan.

Lestari, S. Y. (2017) 'Hubungan Antara Aktivitas Fisik dan Asupan Serat denan Tekanan Darah pada Pasien Hipertensi Di Puskesmas Sentolo I 
Kabupaten Kulon Progo Tahun 2017', Naskah Publikasi Poltekes Kemenkes Yogyakarta.

Martini, S., Roshifanni, S. and Marzela, F. (2018) 'Pola Tidur yang Buruk Meningkatkan Risiko Hipertensi', Media Kesehatan Masyarakat Indonesia, 14(3), p. 297. doi: $10.30597 / \mathrm{mkmi} . \mathrm{v} 14 \mathrm{i} 3.4181$.

MedlinePlus (2017) 'How to Prevent High Blood Pressure', 13 November. Available at: https: / /medlineplus.gov/howtopr eventhighbloodpressure.html.

Memah, M., Kandou, G. D. and Nelwan, J. E. (2019) 'Hubungan antara kebiasaan merokok dan konsumsi alkohol dengan kejadian hipertensi di Puskesmas Kombi Kecamatan Kombi Kabupaten Minahasa', Jurnal Kesmas, 8(1), pp. 68-74.

Pajak, A. et al. (2013) 'Binge Drinking and Blood Pressure: Cross-Sectional Results of the HAPIEE Study', PLoS ONE, 8(6), pp. 1-9. doi: 10.1371 /journal.pone. 0065856 .

Pratiwi, M. W. and Anita, D. C. (2010) 'Hubungan Pola Makan Fast Food Dengan Kejadian Hipertensi Pada Usia Produktif Di Dusun Tegal Ngijon Sumber Agung Moyudan Sleman Yogyakarta'.

Primatesta, P. et al. (2001) 'Evidence From the Health Survey for England', Hypertension, 37, pp. 187-193.

Rahmayani, S. T. (2019) 'Faktor-Faktor Risiko Kejadian Hipertensi Primer pada Usia 20-55 Tahun di Poliklinik Penyakit Dalam RSUD 45 Kuningan', Syntax Idea, 1(4), pp. 100-111.

Sani, M. U. et al. (2010) 'Modifiable cardiovascular risk factors among apparently healthy adult Nigerian population - A cross sectional study', BMC Research Notes, 3(11), pp. 1-7. doi: 10.1186/17560500-3-11.

Sarumaha, E. K. and Diana, V. E. (2018) 'Faktor Risiko Kejadian Hipertensi Pada Usia Dewasa Muda di UPTD Puskesmas Perawatan Plus Teluk Dalam Kabupaten Nias Selatan', Jurnal Kesehatan Global, 1(2), p. 70. doi: $10.33085 / \mathrm{jkg} . v 1 \mathrm{i2} 2.3914$.

Sesso, H. D. et al. (2008) 'Alcohol consumption and the risk of hypertension in women and men', Hypertension, 51(4 PART 2 SUPPL.), pp. 1080-1087. doi: 10.1161/HYPERTENSIONAHA.107.1 04968.

Sriani, K. I., Fakhriadi, R. and Rosadi, D. (2016) 'Hubungan antara Perilaku Merokok dan Kebiasaan Olahraga dengan Kejadian Hipertensi pada Laki-Laki Usia 18 - 44 Tahun (Studi Observasional di Wilayah Kerja Puskesmas Sungai Besar Kecamatan Banjarbaru Selatan)', Jurnal Publikasi Kesehatan Masyarakat Indonesia, 3(1), pp. 16.

Suci Khasanah, M. P. I. susanti (2019) 'Studi Kestabilan Tekanan Darah pada Penderita Hipertensi dan Faktor yang Mempengaruhinya', Viva Medika, 11(2), pp. 84-96.

Wakabayashi, I. (2008) 'Influence of Gender on the Association of Alcohol Drinking With Blood Pressure', American Journal of Hypertension, 21(12), pp. 13101317. doi: 10.1038/ajh.2008.299.

WHO (2019) 'Hypertension', 17 November. Available at: https: //www. who.int/news$\mathrm{room} /$ factsheets/detail/hypertension.

Wijaya, S. A. (2011) 'Hubungan Pola Makan dengan Tingkat Kejadian Hipertensi pada Lansia di Dusun 14 Sungapan Tirtorahayu Galur Kulon Progo Yogyakarta', Program Studi Ilmu Keperawatan Sekolah Tinggi Ilmu Kesehatan 'Aisyiyah Yogyakarta, pp. 1-14.

World Health Federation (2017) 'Risk Factor', Fact Sheet Hypertension, 30 May. Available at: https: / /www.world-heartfederation.org/resources/riskfactors/.

World Health Organizati (2017) Raised blood pressure (SBP $\geq 140$ OR DBP $\geq 90$ ), crude (\%) Estimates by WHO region. In: blood pressure. Available at: http://apps.who.int/gho/data/vi ew.main. NCDBPCREGv?lang=en (Accessed: 21 October 2019).

World Health Organization (2013) A Global Brief on Hypertension, WHO. Geneva. Available at: www.who.int.

World Health Organization (2017) Raised 
Blood Pressure. Available at: https: //www.who.int/gho/ncd/ri sk_factors/blood_pressure_preval ence_text/en/_(Accessed: 21 October 2019).

(Accessed: 21

Yulia, E. (2015) 'MEROKOK, MENGKONSUMI ALKOHOL, DAN
POLA MAKAN DENGAN KEJADIAN HIPERTENSI PADA LANSIA', Jurnal Ilmiah Ilmu Kesehatan: Wawasan Kesehatan. STIKes Kapuas Raya, (Vol 1, No 2 (2015): Vol 1, No 2 (Januari 2015)), pp. 59-68. 